\title{
Pollen productivity estimates of key European plant taxa for quantitative reconstruction of past vegetation: a review
}

\author{
Anna Broström • Anne Birgitte Nielsen · Marie-José Gaillard · Kari Hjelle · Florence Mazier · \\ Heather Binney $\cdot$ Jane Bunting $\cdot$ Ralph Fyfe $\cdot$ Viveca Meltsov $\cdot$ Anneli Poska $\cdot$ Satu Räsänen · \\ Welmoed Soepboer $\cdot$ Henrik von Stedingk $\cdot$ Henna Suutari $\cdot$ Shinya Sugita
}

Received: 31 October 2007/ Accepted: 20 February 2008/Published online: 8 May 2008

(C) Springer-Verlag 2008

\begin{abstract}
Information on the spatial distribution of past vegetation on local, regional and global scales is increasingly used within climate modelling, nature conservancy and archaeology. It is possible to obtain such information from fossil pollen records in lakes and bogs using the landscape reconstruction algorithm (LRA) and its two models, REVEALS and LOVE. These models assume that reliable pollen productivity estimates (PPEs) are available for the plant taxa involved in the quantitative
\end{abstract}

Communicated by J. Dearing.

\section{A. Broström ( $\square)$}

Geobiosphere Science Centre, Lund University, Sölvegatan 12,

22362 Lund, Sweden

e-mail: Anna.Brostrom@geol.lu.se

\section{A. B. Nielsen}

Department of Quaternary Geology,

Geological Survey of Greenland and Denmark, Ø. Voldgade 10,

1350 Copenhagen, Denmark

M.-J. Gaillard · F. Mazier

School of Pure and Applied Natural Sciences,

University of Kalmar, 39182 Kalmar, Sweden

\section{K. Hjelle}

Natural History Collections, University of Bergen, 5007 Bergen, Norway

\section{F. Mazier}

Faculty of Science, UMR 6565, 25000 Besançon, France

\section{H. Binney}

Palaeoecology Laboratory, University of Southampton, University Road, Southampton SO1 7BJ, UK

\section{J. Bunting}

Department of Geography, University of Hull, Kingston-Upon-Hull HU6 7RX, UK reconstructions of past vegetation, and that PPEs are constant through time. This paper presents and discusses the PPEs for 15 tree and 18 herb taxa obtained in nine study areas of Europe. Observed differences in PPEs between regions may be explained by methodological issues and environmental variables, of which climate and related factors such as reproduction strategies and growth forms appear to be the most important. An evaluation of the PPEs at hand so far suggests that they can be used in modelling applications and quantitative reconstructions of past

\section{R. Fyfe}

School of Geography, University of Plymouth,

Plymouth PL4 8AA, UK

V. Meltsov $\cdot$ A. Poska

Institute of Geology at Tallinn University of Technology,

Ehitajate tee 5, 19086 Tallinn, Estonia

S. Räsänen · H. Suutari

Department of Geography, University of Oulu, P.O.Box 3000,

90014 Oulu, Finland

W. Soepboer

Department of Palaeoecology,

Institute of Environmental Biology,

Laboratory of Palaeobotany and Palynology,

Utrecht University, Budapestlaan 4,

3584 CD Utrecht, The Netherlands

H. von Stedingk

Department of Forest Ecology and Management,

Swedish University of Agricultural Sciences,

90183 Umeå, Sweden

\section{S. Sugita}

University of Minnesota, Ecology, Evolution, and Behavior, 100 Ecology Building, 1987, Upper Buford Circle, St Paul, MN 55108, USA 
vegetation, provided that consideration of past environmental variability within the region is used to inform selection of PPEs, and bearing in mind that PPEs might have changed through time as a response to climate change. Application of a range of possible PPEs will allow a better evaluation of the results.

Keywords Pollen productivity estimates (PPE) Landscape reconstruction algorithm (LRA) - Tree taxa . Herb taxa $\cdot$ Moss polsters $\cdot$ Lake sediments

\section{Introduction}

One of the major challenges within palaeoecology is to provide quantitative reconstructions of past vegetation at various spatial scales. Information on the spatial distribution of past vegetation is becoming increasingly sought after within various disciplines including climate modelling, nature conservancy and archaeology (Anderson et al. 2006; Berglund et al. 2007; Bradshaw 2007; Gaillard 2000, 2007; Grant and Edwards 2007; Olofsson and Hickler 2007). This information is obtained from fossil pollen records in lakes and bogs. Accurate reconstruction of vegetation from pollen analysis assumes that the spatial scale of vegetation represented by pollen assemblages is understood, and that the inferred vegetation abundances can be translated into a vegetation map, or other vegetation characteristics needed in specific applications. Over the last decades the development of a theoretical framework and models of pollen-vegetation relationships has made such spatial vegetation/landscape reconstructions feasible (Andersen 1970; Davis 1963; Parsons and Prentice 1981; Prentice 1985; Prentice and Parsons 1983; Sugita 1994, 1998). Pollen productivity and dispersal are two major factors that control the representation of the surrounding vegetation in pollen records from basins of given sizes (Prentice 1985). Sugita (2007a, b) has proposed the landscape reconstruction algorithm (LRA) to obtain estimates of vegetation abundance on local $\left(<1 \mathrm{~km}^{2}\right.$ up to ca. $\left.5 \mathrm{~km}^{2}\right)$ to regional $\left(10^{4}-10^{5} \mathrm{~km}^{2}\right)$ scales. Pollen productivity estimates (PPEs) for the relevant plant taxa are one of the key input parameters of the LRA and its two models, regional estimates of vegetation abundance from large sites (REVEALS) (Sugita 2007a) and local vegetation estimates (LOVE) (Sugita 2007b). One of the important assumptions of these models is that PPEs are constant over time and within a taxon for a given vegetation region.

The REVEALS model has been developed to estimate regional vegetation abundance using pollen from multiple large sites $\left(\geq 1-5 \times 10^{2}\right.$ ha). It has been validated in southern Sweden (Hellman et al. 2008a, b) and applied on two sites that cover the entire Holocene (Sugita et al. 2008). The LOVE model reconstructs vegetation abundance within the relevant pollen source area (sensu Sugita 1994) for smaller sites $\left(>10^{2}\right.$ ha) by using regional vegetation abundance estimates to calculate the background pollen loading and subtracting it from the pollen assemblages. Validation of the LOVE model is in progress in southern Sweden, Denmark, Switzerland, and the upper Great Lakes region of the USA. Preliminary results (Sugita et al., unpublished) have shown that the LOVE model works well to predict the local vegetation composition within the relevant pollen source area, using pollen data from moss polsters and small lakes in southern Sweden (Broström et al. 1998, 2004; Gaillard et al. 1998), and small woodland hollows in northern Michigan and northwestern Wisconsin (Calcote 1995; Parshall and Calcote 2001).

Besides the LRA, applications of the simulation approach POLLSCAPE (Sugita 1994) also require that PPEs for the plant taxa involved are available. For instance, by using PPEs as one of the input variables in models of pollen dispersal and deposition, pollen loadings from a landscape to a basin can be simulated (Nielsen 2004; Sugita et al. 1998, 1999; Gaillard et al. 2008). Such simulations can provide useful insights into pollenvegetation relationships (Bunting et al. 2004; Sugita 1994; Sugita et al. 1999; Gaillard et al. 2008), and make it possible to test hypotheses of past vegetation patterning (Bunting and Hjelle 2008; Caseldine and Fyfe 2006; Caseldine et al. 2007a, b; Fyfe 2006; Gaillard et al. 2008).

Attempts to quantify past vegetation using the LRA and POLLSCAPE approaches are in progress in more than ten study areas in Europe, USA, Africa (see Duffin and Bunting 2007) and Japan (NordForsk-POLLANDCAL network; http://www.ecrc.ucl.ac.uk/pollandcal/). An important part of this process is calculating PPEs for the major taxa of these regions. The distribution of taxa between these regions is controlled by both biotic and abiotic factors, for example climate, competition and disturbance. Such environmental factors may also influence the pollen productivity of species (Broström et al. 2004); this necessitates generation and comparison of PPEs of taxa between regions. PPEs can be calculated from modern pollen and vegetation data using extended $R$ value (ERV) models (Parsons and Prentice 1981; Prentice and Parsons 1983; Sugita 1994) that enable calibration between interdependent pollen percentage data and vegetation composition. To approximate a pollen sample's view of the landscape, the vegetation data used in ERV models is distance-weighted (Prentice and Webb 1986) by applying a species-specific dispersal function (Prentice 1985; Sugita 1993) or less sophisticated methods (Broström et al. 2004). 
Vegetation data may be expressed in various units, for example biomass, leaf cover, rooted frequency, each of which give a unique vegetation estimate that has an effect on the resulting PPEs. PPEs are not absolute values; they are expressed relative to one of the taxa involved in the calculation.

This paper presents a review of the PPEs obtained across Europe for 15 tree and 18 herb taxa. Similarities and differences between PPEs are discussed and recommendations for future PPE studies are proposed.

\section{Study areas}

The study areas for the pollen productivity estimates reviewed in this paper are distributed in northern and central Europe (Fig. 1). Pollen samples have been obtained either from moss polsters (Finland, central and southern Sweden, Norway, England and the Swiss Jura) or from lake sediments (Estonia, Denmark and the Swiss Plateau). Summary data for each study area are presented in Table 1.

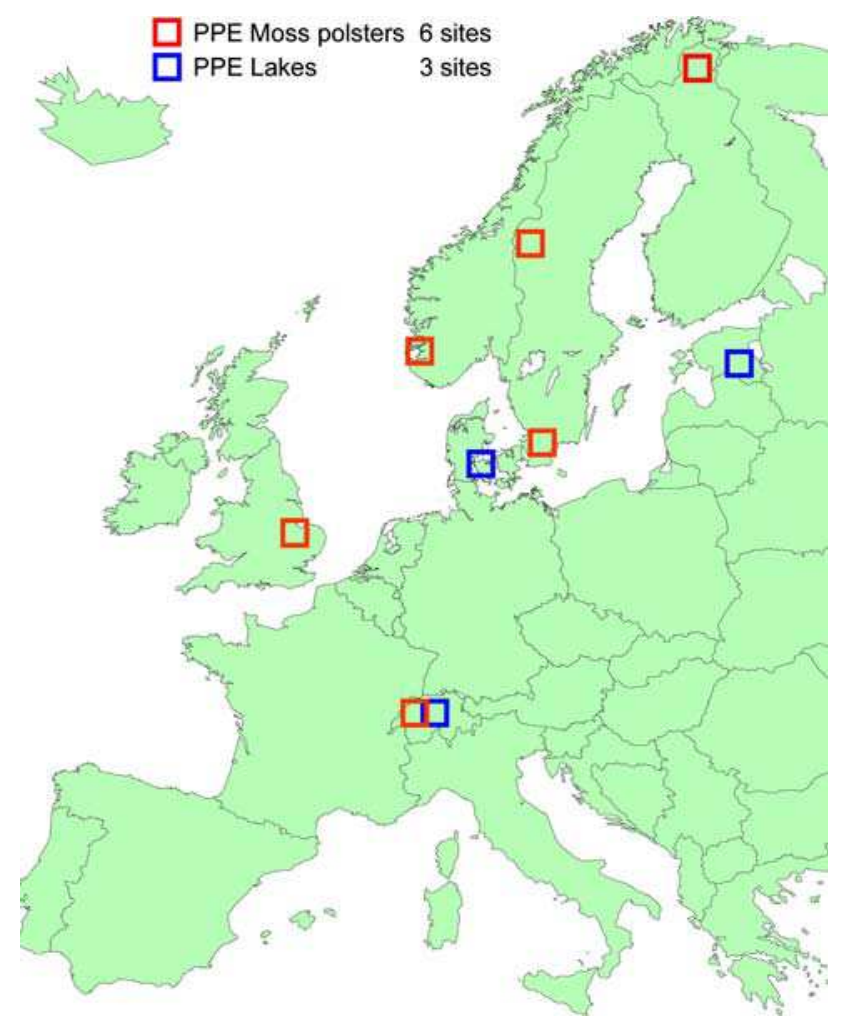

Fig. 1 Location of the nine study areas in Europe from which pollen productivity estimates have been calculated from pollen-vegetation data sets
Finland (Fig. 2a; Räsänen et al. 2007)

The study area is located between the northern limits of Picea abies and Pinus sylvestris in the northern boreal forest vegetation belt of northern Finland. The landscape is a mosaic of large woods, mires of varying sizes (small patch to dozens of square kilometres), numerous lakes and treeless mountain tops with alpine heath vegetation. The woods are dominated by $P$. sylvestris except on the higher elevations, where they are comprised of Betula pubescens ssp. czerepanovii forming the tree line at ca. $400 \mathrm{~m}$ a.s.l. The undergrowth is characterised by dwarf shrubs (Vaccinium vitis-idaea, V. myrtillus, V. uliginosum, Empetrum nigrum ssp. hermaphroditum), Juniperus communis and Betula nana.

Central Sweden (Fig. 2b; von Stedingk et al. 2008)

The study area is situated at the forest-tundra ecotone of the Scandes mountains, west central Sweden. The area is rich in mires with sloping fens totally covering the terrain in some parts. The low alpine tundra zone is characterised by dwarf shrub heath. It includes the sub-alpine coniferous woods, the sub-alpine mountain birch, and the low alpine tundra zones. The woodland limit is formed by Betula pubescens ssp. czerpanovii and some scattered groups of Picea abies often growing in clones with prostrate growth due to snow weight and wind. The sub-alpine woodland consists mainly of $P$. abies and B. pubescens ssp. czerpanovii. Pinus sylvestris is restricted to the northern part of the area. The field layer is characterised by meadow vegetation on fertile soils or ericaceous communities on poorer soils.

Southern Sweden (Fig. 2c; Broström et al. 2004, Sugita et al. 1999)

The study area in southern Sweden consists of two vegetation zones: a southernmost nemoral zone with a potential vegetation dominated by broad-leaved woods and a boreonemoral zone dominated by a mixture of coniferous and broad-leaved deciduous woods. The modern landscape can be subdivided into two distinct regions that correspond approximately to the vegetation zones: (1) a southernmost region characterised by cultivated fields, pastures and small patches of woodland consisting of broadleaved, cool-temperate trees, such as Fagus sylvatica, Quercus robur, Tilia cordata, Fraxinus excelsior, Ulmus glabra and Betula pendula ( $<50 \%$ woodland cover); and (2) a semi-open region characterised by scattered open patches of cultivated fields and pastures within woodland (50-90\% woodland cover) dominated by Picea abies and Pinus sylvestris, while cool temperate broadleaved trees are scattered near farms and in meadows. 
Table 1 Study area, authors, site types, number of sites, number of taxa and scales of vegetation surveys (1) small size detailed survey, (2) intermediate size intermediate degree of detail, (3) large size more generalised survey

\begin{tabular}{|c|c|c|c|c|c|c|c|c|c|c|c|c|c|c|c|c|c|}
\hline \multirow[t]{2}{*}{ Study area } & \multirow[t]{2}{*}{ Authors } & \multirow[t]{2}{*}{$\begin{array}{l}\text { Lat. } \\
(\mathrm{N})\end{array}$} & \multirow[t]{2}{*}{$\begin{array}{l}\text { Long. } \\
\text { (E) }\end{array}$} & \multirow[t]{2}{*}{$\begin{array}{l}\text { Elevation } \\
\text { (m a.s.l.) }\end{array}$} & \multirow{2}{*}{$\begin{array}{l}\text { Temp } \\
\text { Jan } \\
\left({ }^{\circ} \mathrm{C}\right)\end{array}$} & \multirow{2}{*}{$\begin{array}{l}\text { Temp } \\
\text { July } \\
\left(C^{\circ}\right)\end{array}$} & \multirow{2}{*}{$\begin{array}{l}\text { Temp } \\
\text { annual } \\
\left({ }^{\circ} \mathrm{C}\right)\end{array}$} & \multirow{2}{*}{$\begin{array}{l}\text { Annual } \\
\text { precip. } \\
(\mathrm{mm})\end{array}$} & \multirow{2}{*}{$\begin{array}{l}\text { Length of } \\
\text { growing } \\
\text { period } \\
\left(\mathrm{GDD}>5^{\circ} \mathrm{C}\right)\end{array}$} & \multirow[t]{2}{*}{ Vegetation zone } & \multirow[t]{2}{*}{ Major vegetation types } & \multirow[t]{2}{*}{ Site type } & \multirow[t]{2}{*}{$\begin{array}{l}\text { No of } \\
\text { sites }\end{array}$} & \multirow[t]{2}{*}{$\begin{array}{l}\text { No of } \\
\text { taxa }\end{array}$} & \multicolumn{3}{|c|}{$\begin{array}{l}\text { Vegetation survey } \\
\text { radius }(\mathrm{m})\end{array}$} \\
\hline & & & & & & & & & & & & & & & (1) & (2) & (3) \\
\hline Finland & Räsänen et al.(2007) & $68^{\circ} 50^{\prime}$ & $27^{\circ} 30^{\prime}$ & $100-500$ & -16 & 13 & -1 & 500 & 120 & Northern boreal & $\begin{array}{l}\text { Pine woods, birch woods, } \\
\text { mires }\end{array}$ & $\begin{array}{l}\text { Moss } \\
\text { polsters }\end{array}$ & 24 & 6 & 10.5 & & 10,000 \\
\hline Sweden C & $\begin{array}{l}\text { von Stedingk et al. } \\
(2008)\end{array}$ & $63^{\circ} 35^{\prime}$ & $12^{\circ} 20^{\prime}$ & $450-900$ & -7 & 11 & 0 & $\begin{array}{l}650- \\
900\end{array}$ & $130-140$ & Subalpine & $\begin{array}{l}\text { Coniferous woodland, birch } \\
\text { woodland, alpine tundra }\end{array}$ & $\begin{array}{l}\text { Moss } \\
\text { polsters }\end{array}$ & 30 & 9 & 10 & 100 & 1,500 \\
\hline Sweden S & $\begin{array}{l}\text { Sugita et al. (1999) } \\
\text { Broström (2002) } \\
\text { Broström et al. } \\
(2004)\end{array}$ & $55-59^{\prime}$ & $12-17^{\circ}$ & $0-300$ & -1 & 15 & $5-7$ & $\begin{array}{l}600- \\
1,000\end{array}$ & $180-210$ & $\begin{array}{l}\text { Nemoral/ } \\
\text { Boreo-nemoral }\end{array}$ & $\begin{array}{l}\text { Woodland, cultivated fields, } \\
\text { pasture }\end{array}$ & $\begin{array}{l}\text { Moss } \\
\text { polsters }\end{array}$ & 156 & 26 & 10 & 100 & 1,500 \\
\hline Norway & Hjelle (1998) & $61^{\circ}$ & $5^{\circ} 30^{\prime}$ & $0-100$ & 4 & 17 & $4-8$ & $\begin{array}{l}1,000- \\
3,000\end{array}$ & $210-220$ & $\begin{array}{c}\text { Boreo-nemoral/ } \\
\text { South boreal }\end{array}$ & $\begin{array}{l}\text { Coastal heathland, grazed } \\
\text { and mown grasslands }\end{array}$ & $\begin{array}{l}\text { Moss } \\
\text { polsters }\end{array}$ & $\begin{array}{l}21 \\
s(97)\end{array}$ & 10 & & & \\
\hline England & Bunting et al. (2005) & $52^{\circ} 32^{\prime}$ & $1^{\circ} 14^{\prime}$ & $<100$ & 3 & 16 & & 700 & $240-260$ & Atlantic & $\begin{array}{l}\text { Deciduous woodland, } \\
\text { agricultural land }\end{array}$ & $\begin{array}{l}\text { Moss } \\
\text { polsters }\end{array}$ & 34 & 5 & & & 150 \\
\hline Swiss Jura & Mazier et al. (2008) & $47^{\circ}$ & $7^{\circ}$ & $\begin{array}{l}1100- \\
1550\end{array}$ & -6 & 11 & $3-5$ & 1,600 & $120-135$ & Subalpine & $\begin{array}{l}\text { Woodland pasture, } \\
\text { coniferous/ broadleaved } \\
\text { woods }\end{array}$ & $\begin{array}{l}\text { Moss } \\
\text { polsters }\end{array}$ & 20 & 11 & 10 & 100 & 1,500 \\
\hline Estonia & $\begin{array}{l}\text { Meltsov and Poska } \\
\text { in progress }\end{array}$ & $57^{\circ} 50^{\prime}$ & $27^{\circ}$ & $0-300$ & -7 & 17 & 5 & 700 & $190-200$ & Boreo-nemoral & Woodland, agricultural land & Lakes & 26 & 10 & & & 2,000 \\
\hline Denmark & Nielsen (2004) & $55-57^{\circ}$ & ${ }^{\circ} 8-13^{\circ}$ & $0-150$ & 0 & 16 & 8 & $\begin{array}{l}580- \\
820\end{array}$ & $200-220$ & Nemoral & $\begin{array}{l}\text { Agricultural land, heathland, } \\
\text { broadleaved woodland }\end{array}$ & Lakes & 30 & & & & $2,000^{\mathrm{a}}$ \\
\hline Swiss Plateau & $\begin{array}{l}\text { Soepboer et al. } \\
\quad(2007 \mathrm{a}, \mathrm{b})\end{array}$ & $47^{\circ} 05^{\prime}$ & $8^{\circ} 04^{\prime}$ & $400-700$ & 0 & 17 & 8 & $\begin{array}{l}900- \\
1,350\end{array}$ & & Nemoral & $\begin{array}{l}\text { Agricultural land, } \\
\text { decid./conif. woods }\end{array}$ & Lakes & 20 & 13 & & & 1,190 \\
\hline
\end{tabular}

${ }^{a}$ Data from historical sources, such as maps and written descriptions (Nielsen and Odgaard 2004)

Norway (Fig. 2d; Hjelle 1998)

The study area in western Norway lies within the boreonemoral and southern boreal vegetation zones characterized by broad-leaved deciduous and coniferous woods (Moen 1999). The study focussed on heathland, grazed grassland pastures and mown meadows, which represent old cultural landscapes that are still in traditional use at some farms, although often as small patches within a modern agricultural landscape or within a landscape of woodland regeneration. The coastal heathland is characterized by Calluna vulgaris. The meadows are speciesrich hay meadows mown once a year and grazed in spring and/or autumn, whereas species richness and grazing pressure in the pastures vary between the sites. Galium saxatile, Potentilla erecta, Plantago lanceolata, Ranunculus acris, Rumex acetosa, and several Poaceae species are common.

Denmark (Fig. 2e; Nielsen 2003)

Denmark is located in the nemoral zone with a potential vegetation dominated by broad-leaved woodland, as in southernmost Sweden. The landscape today is heavily affected by agriculture, and modern analogues of past cultural landscapes are rare and of small extent. Therefore, an alternative approach using historical vegetation data and pollen samples dated to A.D. 1800 was used. The advantages and problems with historical analogues are discussed in Nielsen and Odgaard (2004). The A.D. 1800 landscape, as reflected by historical maps, was very open (ca. 7\% woodland cover). The peninsula of Jutland in western Denmark was characterised by very large tracts of Callunadominated heathland on sandy soils, a feature not found in eastern Denmark where the landscape was dominated by agricultural land. Woods were mainly composed of Fagus sylvatica and Quercus robur with smaller amounts of other broadleaved trees.

Estonia (Fig. 2f; Meltsov and Poska, in progress)

The study area in southeastern Estonia has a moderately hilly relief. Estonia is located at the northern limit of the boreo-nemoral forest zone. The present patchy cultural landscape consists of an intricate mixture of woods and open land. Woods are dominated by Pinus sylvestris (41\%), Betula pendula and B. pubescens (29\%), and Picea abies (23\%). Alnus incana, A. glutinosa and Populus tremula occur in smaller amounts. The proportion of temperate deciduous trees, such as Quercus robur, Ulmus glabra, U. laevis, Tilia cordata, Acer platanoides and Fraxinus excelsior is low (Poska et al. 2007).

England (Fig. 2g; Bunting et al. 2005)

PPEs are available from studies carried out in the Broads area of East Anglia. The low-lying landscape once supported extensive basin and floodplain wetlands, which have been much modified by human activity, particularly medieval peat cutting which created the large open water 'Broads'. The dry land areas are now intensively used for agriculture, and only small areas of the original mosaic of 

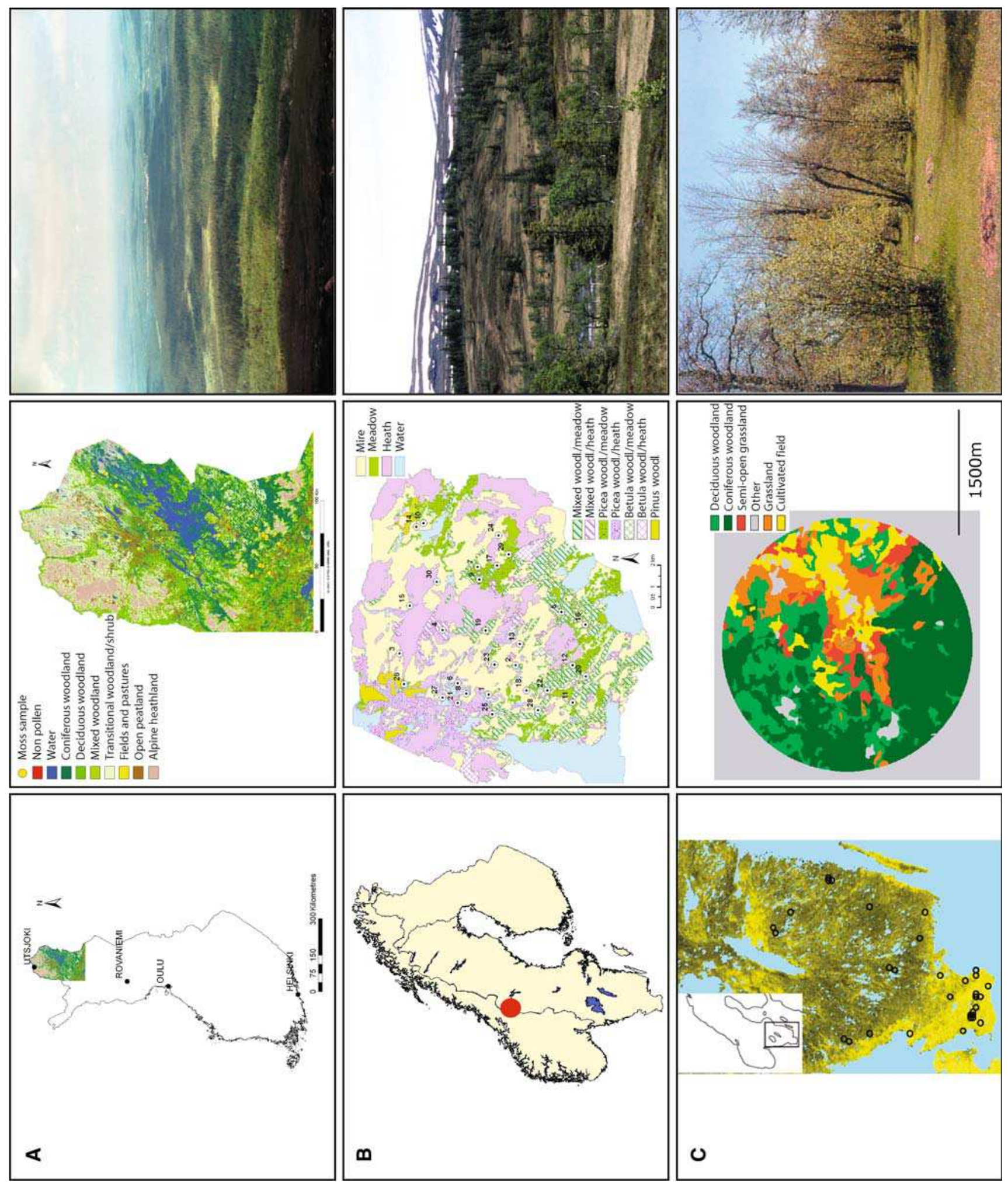

Fig. 2 Regional vegetation maps, site maps and photos from the study areas; a Finland (Räsänen et al. 2007), b central Sweden (von Stedingk et al. 2008), c southern Sweden (Broström et al. 2004; Sugita et al. 1999); d Norway (Hjelle 1998); e Denmark (Nielsen
2003); f Estonia (Meltsov and Poska, in progress); g England (Bunting et al. 2005); h Swiss Jura (Mazier et al. 2008); i Swiss Plateau (Soepboer et al 2007a, b) 

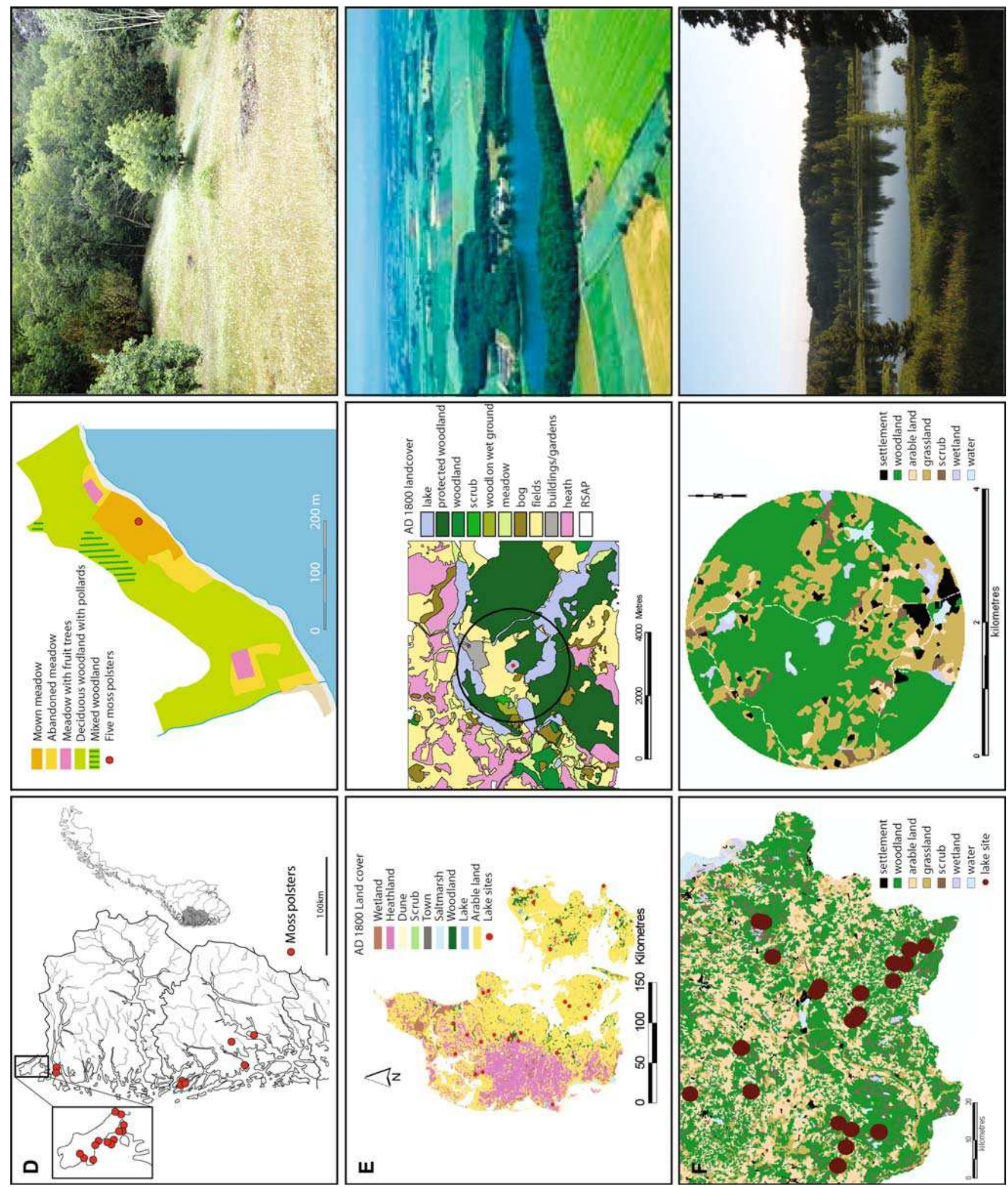

Fig. 2 continued

dry and wet woodland, fen and shallow open water communities survive. Calthorpe Broad is a site centred on a basin wetland, surrounded by dry land woodland dominated by Quercus robur with stands of Fagus sylvatica and Pinus sylvestris to the north and west, and by Betula pubescens to the south. A narrow transitional 

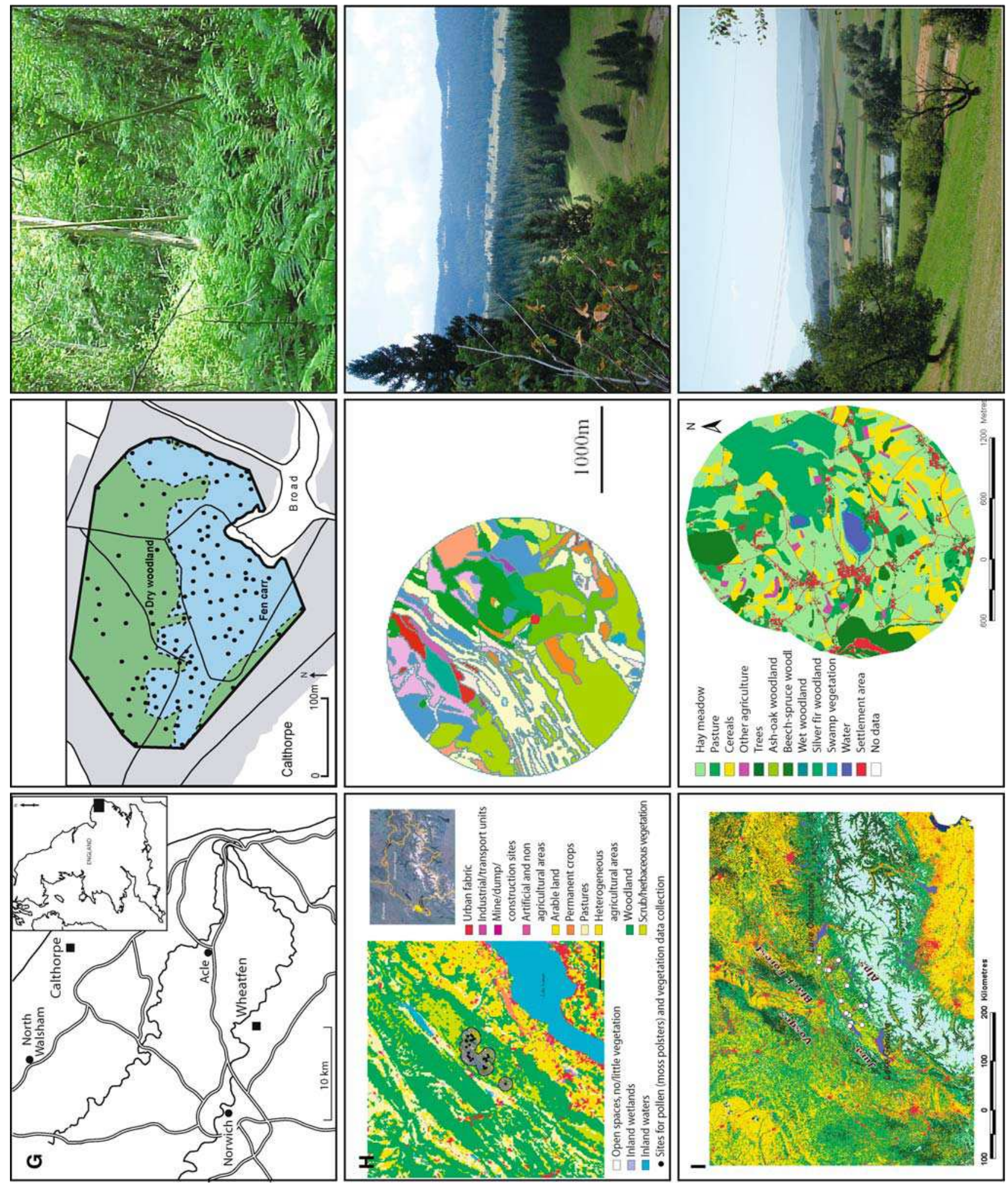

Fig. 2 continued

Fraxinus excelsior zone separates the dry land woodland from Alnus glutinosa dominated carr woodland, centred on the open water and Phragmites australis reedswamp
Broad. Wheatfen is a floodplain wetland showing strong vegetation zonation with distance from the main channel. The studied area consists of Alnus glutinosa and Salix 
cinerea carr woodland, a large area of wet Fraxinus excelsior and Acer pseudoplatanus woodland, and an area of dry land woodland dominated by Quercus robur with an understorey of formerly coppiced Corylus avellana.

Swiss Jura (Fig. 2h; Mazier et al. 2008)

The Swiss Jura Mountains include both the mountain and subalpine vegetation belts. The soils are dry due to the presence of calcareous layers with high permeability (Gallandat et al. 1995). The modern landscape consists of pasture woodlands that are traditional semi-natural ecosystems with natural regeneration of grassland and woodland. The area is characterised by a gradient in the degree of openness from grassland, through wooded pasture and open woods. The region has very high vegetation heterogeneity and biodiversity (Gobat et al. 1989). Coniferous woods, with Picea abies and scattered Abies alba and Acer pseudoplatanus, form the dominant vegetation type over 1,300 m elevation. Broadleaved woods dominated by Fagus sylvatica are found on south facing slopes below $1,400 \mathrm{~m}$ with minimal grazing pressure.

Swiss Plateau (Fig. 2i; Soepboer et al. 2007a, b)

The Swiss Plateau is situated between the Jura mountains in the northwest of Switzerland and the Alps in the southeast. Its elevation is between 300 and $800 \mathrm{~m}$ a.s.l. The relatively flat landscape and most productive soils of the Swiss Plateau have attracted human populations since the Mesolithic. Today the largest cities of Switzerland are found in that area. The landscape is largely still in agricultural use with meadows, pastures and arable land, although urbanisation continues to reduce the area of agricultural land. A quarter of the landscape is occupied by woodlands that are mostly used for timber production, consisting mainly of Picea abies, Fagus sylvatica and Abies alba.

\section{Sampling methods}

Within each study area pollen was extracted from either terrestrial moss polsters or lake sediments. The vegetation data was collected in the field and compiled from remote sensing data such as aerial photos or satellite images. In all study areas except Norway the vegetation surveys were designed to obtain distance weighted plant abundance. However, vegetation surveys varied in terms of sampling methods and the spatial scale of analysis. A summary of the sampling methods used is given below. Information on spatial scale is presented in Table 1. For further, more detailed information, the reader is referred to the original papers.
Moss polster sites

In Finland, central Sweden, southern Sweden and the Swiss Jura, pollen was extracted from moss polsters. The vegetation up to ca. $10 \mathrm{~m}$ from the sampling point was recorded in detail in $1 \mathrm{~m}$ wide concentric rings by visual estimation of percentage cover (Broström et al. 2004). In Sweden and the Swiss Jura, the vegetation communities between 10 and $100 \mathrm{~m}$ were mapped in the field and the vegetation data beyond $100 \mathrm{~m}$ obtained by studying aerial photos. In Finland, the vegetation data beyond $10.5 \mathrm{~m}$ radius was extracted from processed digital raster data, the 'Land cover and forest classification of Finland' (resolution $1 \times 1 \mathrm{~m}$ ), supplied by the National Land Survey of Finland (Fig. 3; Table 1). In all study areas, remotely sensed vegetation classification was checked in the field (Broström et al. 2004; Mazier et al. 2008; Räsänen et al. 2007; Sugita et al. 1999; von Stedingk et al. 2008).

In England and Norway, pollen was also extracted from moss polster samples; however, vegetation surveys were undertaken on a smaller spatial scale. In England vegetation was surveyed in concentric rings around the pollen sampling points (Bunting et al. 2005). Distribution maps of the main tree taxa were generated using aerial photograph analysis and interpretation of canopy composition data collected using a modified pin frame method based on $2 \mathrm{~m}$ radius relevées at over 200 points in the two study areas. In Norway the vegetation data was surveyed within a smaller area using random square metre plots within an area of $10 \times 10 \mathrm{~m}^{2}$, recording presence/absence of taxa. This method provides frequency estimates for each species (Hjelle 1998; Fig. 3, Table 1).

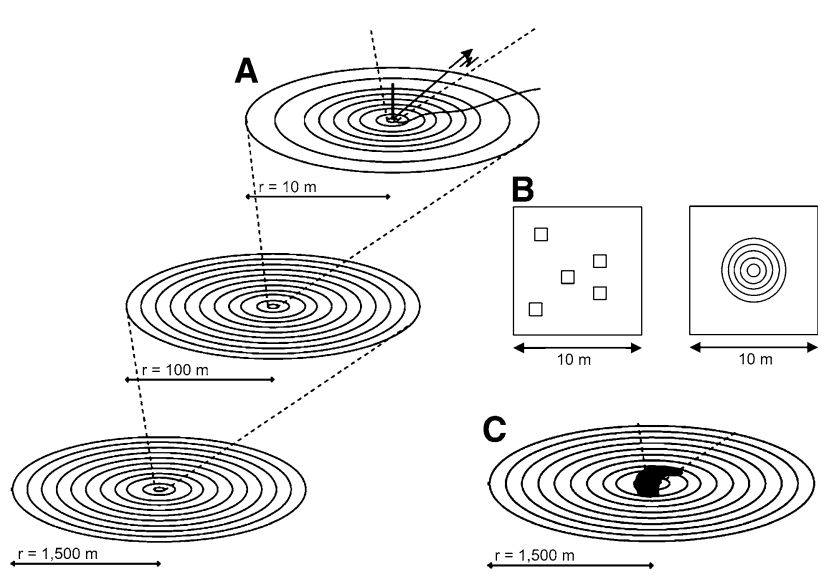

Fig. 3 Vegetation sampling design for: a moss polster sites in Finland, central Sweden, southern Sweden and the Swiss Jura, b moss polster sites in Norway and England, $\mathbf{c}$ lake sites in Estonia, Denmark and on the Swiss Plateau 
Lake sites

In Denmark, Estonia and on the Swiss Plateau, sediment from small lakes (1-30 ha) was sampled for pollen, and the surrounding vegetation surveyed in concentric rings out to 1,000-2,000 m. In Estonia and on the Swiss Plateau, surface sediments were sampled for pollen analysis and modern vegetation was surveyed using aerial photos (Soepboer et al. 2007a, b). In Denmark, lake sediments were sampled for pollen analysis at the A.D. 1800 level as estimated by extrapolation of the ${ }^{210} \mathrm{~Pb}$ chronologies. The vegetation data was extracted from digitised historical maps combined with other historical written sources on tree and crop composition (Nielsen 2003; Nielsen and Odgaard 2004; Fig. 3, Table 1).

\section{Data analysis}

In all studies, except for Norway, distance-weighted plant abundances were calculated for each sampling site from the vegetation data using step-wise taxon-specific distance weightings, which take into account both the distance between the source plant and the pollen sampling point, as well as the dispersal coefficient specific to each taxon. In the Norwegian study (Hjelle 1998) the vegetation data could not be distance-weighted because the vegetation data was not collected for this purpose (Calcote 1995; Prentice 1985; Sugita 1994). Both models are based on Sutton's equation for the diffusion of small particles from a ground level source (Prentice 1985; Sutton 1953). Fall speeds of pollen for the taxa involved were obtained from the literature (Eisenhut 1961; see, for example, Broström et al. 2004; Sugita et al. 1999) or calculated according to Stokes' law (Broström et al. 2004; Gregory 1973).

Pollen counts and corresponding distance-weighted plant abundance data for each site were analysed using computer programs for ERV models (ERV multi and ERV version 6, Sugita unpublished), (Calcote 1995; Sugita 1994; Sugita et al. 1999). There are three ERV models, which are used to estimate a linear relationship between pollen and vegetation data. These differ in terms of data input format and how background pollen is defined (Sugita 1994). ERV models 1 and 2 use pollen and vegetation proportions. ERV model 1 assumes a species-specific constant background in pollen proportion, whereas ERV model 2 assumes a species-specific constant background in the ratio of pollen loading to total plant abundance for all taxa involved (Prentice and Parsons 1983). ERV model 3 uses pollen proportions and absolute plant abundance data and assumes constant background pollen loading between sites (Sugita 1994). The goodnessof-fit of the data to the model-estimated relationship can be visualized if the vegetation or pollen data is transformed. For ERV model 1 the vegetation data are adjusted, while for ERV models 2 and 3 the pollen proportions are adjusted in model-specific ways. When graphically presented as scatter diagrams, the adjusted data show a better linear relationship between pollen and vegetation data than from using the uncorrected data, and the slope $(\alpha)$ and intercept $(z)$ represents the estimated pollen productivity and background component, respectively.

If absolute plant abundance data are available, the interpretation of the background component $(z)$ is most straightforward using ERV model 3 (Sugita 1994). Where plant abundance is expressed as a percentage, either ERV model 1 or 2 should be used. When using relative plant abundance data, both model 1 and 2 should be applied; if they provide comparable estimates of $\alpha$ and $\mathrm{z}$, they can be considered as robust (Prentice and Parsons 1983). Because the two models differ in their treatment of background pollen (see above), large differences in pollen productivity among taxa and in vegetation composition among sites might strain the approximation of model 1 , whereas large differences in total plant abundance between sites might have this effect using model 2 (Prentice and Parsons 1983). In Norway, England and the Swiss Jura, the results from ERV model 1 were retained (Parsons and Prentice 1981; Prentice and Parsons 1983) (for further details on the differences between model results, see Mazier et al. (2008). In all other studies, the results from ERV model 3 were selected.

ERV analysis results in PPEs and likelihood function scores at increasing distances from each site. By plotting likelihood function scores against distance, the relevant source area of pollen (Sugita 1994) can be estimated as the point where an asymptote is reached, which represents the distance at which the pollen-vegetation relationship does not improve. This is the best distance at which to extract PPEs, because PPE values do not change significantly beyond the RSAP (relevant source area of pollen).

PPEs were calculated using Poaceae as a reference taxon (Broström et al. 2004). PPEs have been recalculated for regions, which originally used a different reference taxon (England and tree taxa in southern Sweden). PPEs have not been generated for all taxa in all the study areas: the choice is constrained by the major taxa in the modern vegetation and pollen assemblages in each region and the spread of values within the vegetation-pollen datasets. Reliable PPEs are obtained only if the spread in proportions of the taxon in both vegetation and pollen is large enough (Broström et al. 2004). Pollen taxonomy and nomenclature follows (Moore et al. 1991) and (Punt et al. 1976-1995). 


\section{Results}

Pollen productivity estimates for 18 herb and 15 tree taxa from the nine study areas in Europe are presented in Table 2 and Fig. 4.
There are both high and low pollen producers common to most or all of the nine study areas, although the PPE values for these taxa vary between areas. The tree taxa with consistently high PPEs are Alnus, Betula, Quercus, Pinus and Abies in the two central European study areas. Among

Table 2 Pollen productivity estimates (PPE) for herb and tree taxa from ten study areas in Europe

\begin{tabular}{|c|c|c|c|c|c|c|c|c|c|}
\hline & $\begin{array}{l}\text { Finland } \\
\text { Moss po }\end{array}$ & $\begin{array}{l}\text { Sweden } \\
\text { central } \\
\text { sites }\end{array}$ & $\begin{array}{l}\text { Sweden } \\
\text { south }\end{array}$ & Norway & England & $\begin{array}{l}\text { Swiss } \\
\text { Jura }\end{array}$ & $\begin{array}{l}\text { Estonia } \\
\text { Lake site }\end{array}$ & Denmark & $\begin{array}{l}\text { Swiss } \\
\text { Plateau }\end{array}$ \\
\hline \multicolumn{10}{|l|}{ Reference taxa } \\
\hline Poaceae & 1.00 & 1.00 & 1.00 & 1.00 & & 1.00 & 1.00 & 1.00 & 1.00 \\
\hline \multicolumn{10}{|l|}{ Herb taxa } \\
\hline Apiaceae & & & & 0.26 & & & & & \\
\hline Calluna vulgaris & & 0.30 & 4.70 & 1.07 & & & & 1.61 & \\
\hline Cerealia-t & & & 3.20 & & & & 4.00 & 1.27 & 0.0008 \\
\hline Cichorioideae & & & 0.24 & 0.06 & & & & & 0.17 \\
\hline Cyperaceae & 0.002 & 0.89 & 1.00 & 0.29 & & 0.68 & 0.00 & & \\
\hline Empetrum & 0.07 & 0.11 & & & & & & & \\
\hline Ericaceae & & 0.07 & & & & & & & \\
\hline Filipendula & & & 2.48 & 3.39 & & & 16.10 & & \\
\hline $\begin{array}{r}\text { Leucanthemum } \\
\text { (Anthemis)- } \mathrm{t}\end{array}$ & & & & 0.10 & & & & & \\
\hline Plantago lanceolota & & & 12.76 & 1.99 & & & & 0.46 & 0.24 \\
\hline Plantago media & & & & & & 1.43 & & & \\
\hline Plantago montana & & & & & & 0.77 & & & \\
\hline Potentilla-t & & & 2.47 & 0.14 & & 0.58 & & & \\
\hline Ranunculus acris-t & & & 3.85 & 0.07 & & & & & \\
\hline Rubiaceae & & & 3.95 & 0.42 & & 2.64 & & & \\
\hline Rumex acetosa-t & & & 4.74 & 0.13 & & & & 0.35 & \\
\hline Trollius & & & & & & 1.17 & & & \\
\hline Vaccinium & 0.01 & & & & & & & & \\
\hline \multicolumn{10}{|l|}{ Tree taxa } \\
\hline Abies & & & & & & 3.34 & & & 9.92 \\
\hline Acer & & & & & & 0.35 & & & \\
\hline Alnus & & & 4.20 & & 11.40 & & 18.00 & & \\
\hline Betula & 4.60 & 2.24 & 8.90 & & 8.06 & & 6.80 & & 2.42 \\
\hline Carpinus & & & & & & & & & 4.56 \\
\hline Corylus & & & 1.40 & & & & 0.20 & & 2.58 \\
\hline Fagus & & & 6.70 & & & 1.39 & & 3.60 & 0.76 \\
\hline Fraxinus & & & 0.70 & & 0.91 & & & & 1.39 \\
\hline Juniperus & & 0.11 & 2.10 & & & & & & \\
\hline Picea & & 2.78 & 1.80 & & & 7.10 & 4.80 & 4.75 & 0.57 \\
\hline Pinus & 8.40 & 21.58 & 5.70 & & & & 6.80 & 1.41 & 1.35 \\
\hline Quercus & & & 7.60 & & 7.60 & & & & 2.56 \\
\hline Salix & & 0.09 & 1.30 & & 1.37 & & & & \\
\hline Tilia & & & 1.30 & & & & & & \\
\hline Ulmus & & & 0.80 & & & & & & \\
\hline Number of taxa & 6 & 10 & 25 & 9 & 6 & 11 & 10 & 8 & 13 \\
\hline
\end{tabular}

PPEs were estimated using ERV model 3 and Poaceae as reference taxa, except for Norway, England and the Swiss Jura, for which ERV model 1 was applied 
Fig. 4 Pollen productivity estimates with error estimates for major taxa

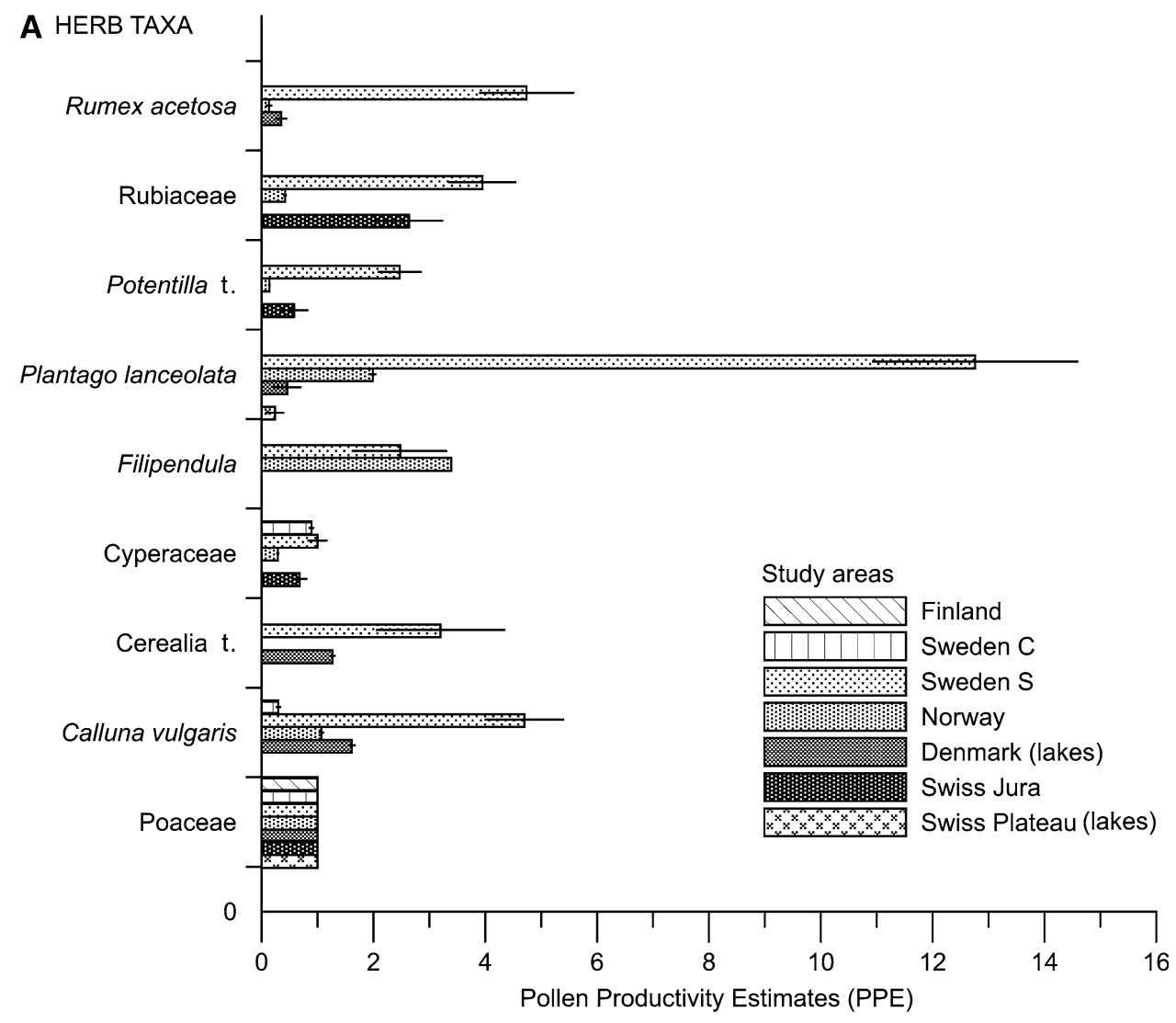

B TREE TAXA

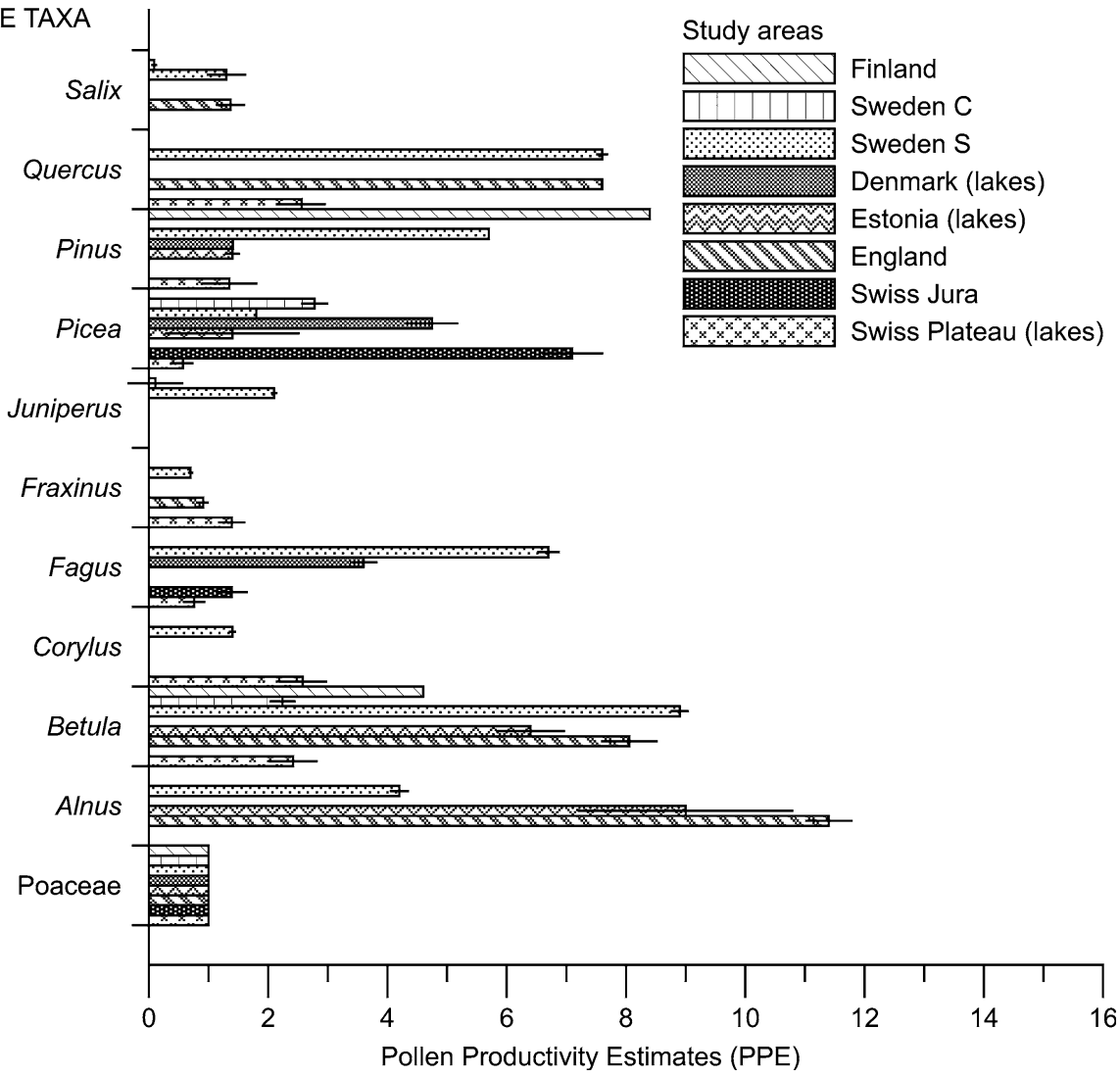


the herbs, Calluna and Filipendula are high pollen producers in all study areas with the exception of Calluna in the subalpine vegetation of central Sweden. Plantago lanceolata, Potentilla type, Ranunculus acris type, Rubiaceae (Galium type) and Rumex acetosa type are also relatively high pollen producers; however, they have systematically higher PPEs in southern Sweden than in Norway and values in the Swiss Jura that are closer to the southern Swedish than the Norwegian values.

The low pollen producers among the tree taxa are Fraxinus, Salix, Tilia and Ulmus. Among the herbs in the subalpine vegetation, Empetrum, Ericaceae and Vaccinium have low PPEs. In the cultural landscape of the nemoral and boreo-nemoral vegetation zones, Apiaceae, Compositae subfamily Cichorioideae and Leucanthemum (Anthemis type) are low producers. In the study areas where PPEs for both trees and herbs were obtained, the tree taxa have higher PPEs than herbs in Finland, central Sweden, Denmark and on the Swiss Plateau. In Estonia, southern Sweden and the Swiss Jura some herb taxa have higher PPEs than some tree taxa (Table 2).

When comparing PPEs from regions characterised by comparable vegetation and climate, discrepancies between values may be large. The PPEs obtained in the Jura mountains (from moss polsters) for Picea, Fagus and Plantago ( $P$. lanceolata on the Swiss Plateau, P. media and $P$. montana in the Swiss Jura) are significantly higher than those estimated for the Swiss Plateau (from lake sediments), while Abies PPEs are higher on the Swiss Plateau. In the case of southern Scandinavia and Estonia, the tree PPEs from southern Sweden (from moss polsters) are lower than those from Denmark (A.D. 1850 lake sediments) and Estonia (surface lake sediments), except for Betula, Fagus and Picea. The largest difference is seen in the PPEs for Alnus that are very high in Estonia (18.00) compared to southern Sweden (4.20). Other discrepancies are found in the PPEs for Picea and Pinus: Picea has a lower PPE than Pinus in southern Sweden (1.80/5.70), higher PPE than Pinus in Denmark (4.75/1.41), and almost as high PPE as Pinus in Estonia (4.80/6.80). The PPEs values for Pinus in southern Sweden and Estonia are comparable (5.70/6.80). The PPEs from England for Betula, Fraxinus, Quercus and Salix are comparable to the values from southern Sweden and Estonia and the PPE for Alnus (11.40) is closer to that of Estonia (18.0) than that from southern Sweden (4.20). The PPEs from northern Scandinavia are generally lower than the PPEs from southern Scandinavia and central Europe. Nevertheless, the PPE for Cyperaceae is very low in northern Finland (0.002), while it is close to the southern Swedish (1.0) and Swiss Jura (0.68) values in central Sweden (0.89). The PPEs for Salix are in relatively good agreement in the study regions, which generated values for this taxon, central and southern Sweden (0.09 and 1.30, respectively), and England (1.37).

\section{Discussion}

The possible factors behind the observed differences in PPEs may be grouped into two types: (1) methodological factors, such as differences in the type of site (vegetation on drained soils, wetland, lake), pollen sample (moss polster, modern or fossil lake sediments), the method of vegetation survey, and the length of the gradient in the plant and pollen data values; and (2) environmental factors, such as differences in climate, vegetation structure and species composition, and land-use/landscape management between the study areas. Further, this review compares relative values, that is, PPEs relative to the pollen productivity of Poaceae. The comparison is therefore based on the assumption that the pollen productivity of Poaceae is more or less the same in all study areas, which is not necessarily the case because of differences in the species involved and in land-use and climate conditions. It follows that the evaluation of the comparison is complex and, in some cases, tentative.

\section{Methodological factors}

Poaceae has become a standard reference taxon in PPE studies including herbs (Broström et al. 2004; Hjelle 1998), although it is not an ideal reference taxon since it includes more than one species, and different regions are likely to include different species. However, Poaceae is a widespread taxon, abundant in modern and fossil pollen records of most regions of the world; it has been shown as an intermediate pollen producer in all PPE studies. Further, the taxon has a large spread of values in the pollen-vegetation data sets of most study areas, which is an advantage for a reference taxon. For all these reasons, Poaceae has been considered as the most practical reference taxon. However, the species included in this pollen type may differ in their pollen production and, therefore, the relative PPEs of other taxa may differ from region to region. Two studies have used different reference taxa: in England Bunting et al. (2005) used Quercus while Sugita et al. (1999) used Juniperus for tree taxa in southern Sweden. However, these two taxa are not represented in all datasets discussed here. Moreover, there is no other taxon than Poaceae that is present and has a good spread of values in all the pollen-vegetation datasets. Therefore, there is no alternative to Poaceae as a reference taxon for comparison of PPEs between regions in Europe. In the discussion below, the possible effect on PPEs of using Poaceae should always be kept in mind. 
Both moss polsters and lake sediments have been used to obtain PPEs in Europe. It is known from extensive pollen trap studies that there is a high annual variability in pollen production (Hicks 1998, 2001). This implies a need for time-averaged PPEs if they are to be used in vegetation reconstructions inferred from fossil pollen assemblages, representing a minimum of 10 years (with the exception of annually laminated deposits). It has generally been assumed that moss polsters include pollen deposition from more than one year; however, Räsänen et al. (2004) have shown that moss polsters typically trap 1-2 years pollen. In the PPE studies discussed in this paper, the pollen data from modern lake sediments (Swiss Plateau and Estonia) and from historical lake sediments (A.D. 1850, Denmark) are likely to represent a longer time period of pollen deposition than moss polsters.

PPEs from moss polsters and lake sediments should be comparable since the distance-weighting models used in the calculations (bog model, Prentice 1985; lake model, Sugita 1993) are based on the same assumptions and basic model of the pollen-vegetation relationship. However, there are major differences between PPEs from lake sediments and moss polster samples although these differences are not always consistent. The PPEs for Alnus (England and Estonia) and Filipendula (Estonia) based on lake surface samples (Estonia) and on moss polsters in carr woodland (England) are markedly higher than the PPEs generated from moss polster samples from other regions. This may be a taphonomic bias with littoral vegetation over-represented in the lake sediments (Estonia) or on the woodland carr in the centre of the vegetation survey (England) and the failure of the distance-weighting function to correct this effect, or an underestimation of these taxa in the vegetation survey outside the lakes' direct vicinity (the latter is considered more probable then the former). Alternative explanations for the differences in PPEs for Alnus between England and southern Sweden are suggested below. Plantago lanceolata, on the other hand, has lower PPEs when inferred from lake sediment data (Denmark, Swiss Plateau) than from moss polster data (Norway and Sweden). These results may reflect poor dispersal of Plantago lanceolata pollen into lakes, and under-representation of certain pollen types in lake sediments compared to moss polsters (Wilmshurst and McGlone 2005). Since a large spread of values both in vegetation abundance and pollen proportions is important to obtain robust PPEs (Parsons and Prentice 1981; Prentice and Parsons 1983), the optimal choice of deposit may vary between taxa. For example, taxa, which are poorly represented in lake sediments, for example entomophilous herbaceous taxa, may require PPEs to be generated from moss polster samples.
Different methods of vegetation survey may be a possible cause behind differences in PPEs between studies (Bunting and Hjelle 2008). The majority of estimates are based on vegetation cover data; however, the estimates from Norway are based on non-distance-weighted vegetation frequency data within square metre plots. This appears to have resulted in generally lower PPEs for herb taxa in the Norwegian study possibly as a result of overrepresentation of taxa in the vegetation dataset. As accurate vegetation data is critical in the generation of PPEs, differences in methods, which result in different estimates of vegetation cover will influence PPE values. For example, use of canopy data has produced a much higher PPE for Alnus in England compared to that obtained in southern Sweden. However, the spread of values within the vegetation and pollen datasets of Alnus in England may offer an alternative explanation for the high PPE for this taxon in this area.

The PPEs for herbs in southern Sweden are generally higher than in the other regions. Plantago lanceolata, Cerealia, Potentilla type, Ranunculus acris type, Rubiaceae and Rumex acetosa type in the southern Swedish dataset are all characterised by a small spread of values in the vegetation data with a few outliers characterised by high pollen proportions, which explains high PPEs. Filipendula in Estonia, Alnus in England and especially Pinus in northern Sweden also show a small spread of values in the vegetation data and high PPEs. These examples demonstrate the importance of as large a spread of values as possible in the pollen-vegetation dataset in order to obtain reliable PPEs.

\section{Environmental factors}

Pollen productivity is influenced by temperature. In northern Finland and mountainous areas of Europe, Autio and Hicks (2004) have demonstrated a positive relationship between pollen productivity of Pinus, Picea and Betula and summer temperatures of the previous year. This implies that pollen productivity of a taxon should differ between climatically contrasting study areas such as those presented here. The study area in Finland has the most extreme climate in terms of low January and July temperatures (Table 1). Central Sweden and the Swiss Jura mountains are characterised by very similar temperature regimes, but annual precipitation is greater in the Jura. The climatic characteristics in southern Sweden, Denmark, Norway, England, Estonia and the Swiss Plateau are broadly comparable; however, mean January temperatures are slightly lower in southern Sweden, and annual precipitation is significantly higher in south-western Norway (Table 1).

Some dissimilarities seen in the PPEs might be explained by climatic factors. This is the case for Betula, 
Juniperus and Calluna which all have a lower PPE in northern subalpine areas where these taxa are close to their range limits. The high PPEs for Betula found in southern Sweden, England and Estonia reflect the high pollen production of this taxon, which is also confirmed by the high values of Betula pollen commonly found in trap studies (Hicks 1998). Therefore, lower PPEs of Betula in northern Finland and central Sweden may be explained by climatic factors, whereas the low value from the Swiss Plateau is more difficult to explain (and possibly related to methodological differences). Two other tree taxa, Fagus sylvatica and Picea abies, are characterised by very different PPEs between study areas. The PPEs of Fagus sylvatica are significantly lower in Switzerland than in southern Scandinavia. The low PPE in the Swiss Jura may be caused by suppression of flowering at the altitudinal range limit of the species, while the low PPE from the Swiss Plateau might be due to the low representation of Fagus sylvatica in the vicinity of lake sites. Favourable climatic conditions for Picea abies in the Swiss Jura may have resulted in a high PPE. In addition, the structure of woodland pasture in this region may result in a greater number of flowers on individual trees than in the dense spruce plantations of the Swiss Plateau, southern Scandinavia and Estonia, all of which have a lower PPE for the species.

Variation in PPEs between study areas may reflect differences in the species and sub-species that comprise individual pollen taxa. Direct comparison of PPEs for taxa of which pollen can be identified to species level (Calluna vulgaris, Empetrum nigrum, Filipendula ulmaria, Plantago lanceolata, P. media, P. montana, Trollius europaeus, Juniperus communis, Abies alba, Carpinus betulus, Corylus avellana, Fagus sylvatica, Fraxinus excelsior and Picea abies) is possible. However, ca. 50\% of the taxa for which PPEs were calculated are comprised of several plant species. Moreover, the pollen types including several genera and/or species may include different genera/species depending on the region. This implies that the PPEs may be based on the pollen productivities of different species depending on the region, which might influence their values. Further, vegetation structure and differences in reproduction strategies and growth forms between and within species might influence pollen productivity (von Stedingk et al. 2008). It is well established that many species flower less within woods than in open vegetation, for example Corylus avellana and Juniperus communis. Differences in community structure and the ecological niche a species is occupying may therefore have a strong control on its PPE. Given the range of possible controls on PPEs outlined here it is not possible, within these datasets, to isolate all these factors; however, this remains a likely control on pollen productivity that needs to be explored.
A good example of the possible effect of differing growth forms is found in the PPEs of Juniperus in central and southern Sweden (von Stedingk et al. 2008). In addition to the possible direct effect of contrasting climate between the two regions, the difference in PPEs might also be linked indirectly to the climate factor, that is to the difference in growth forms of this taxon between the two regions, the tall-growing shrubs/trees J. communis ssp. communis L. in the south, and the prostrate J. communis ssp. nana (Willd.) in central Sweden. This may influence the PPEs obtained due to large differences in the number of flowers per unit surface. Low PPEs for Cyperaceae and Empetrum in northern Finland might be other examples where the species involved are characterised by vegetative reproduction rather than abundant flowering because of more severe climate conditions. The most serious possible consequences on PPE values of different species being included in one pollen type is the use of Poaceae as the reference taxon to calculate the relative PPEs of other taxa (see Discussion).

Quantification of agricultural land cover in the past is likely to rely on robust PPEs for Cerealia types. Differences in PPEs for Cerealia types in the data reviewed here (Table 2) may be explained by the species involved in the pollen-morphological type. In southern Sweden, most cultivated cereals in the study areas are of the genus Hordeum (which includes genera of wild grasses such as Bromus). In Denmark, the Cerealia pollen type comprises a mixture of Secale, Hordeum and Triticum. In Estonia, the Cerealia pollen type is dominated by Secale type whilst on the Swiss Plateau it is dominated by Triticum. The PPEs for cereal types from these regions (Table 2) suggest that $\mathrm{Se}$ cale is the most prolific pollen producer (Estonia: 4.0), followed by Hordeum (southern Sweden: 3.2) and Triticum (Swiss Plateau; 0.0008). However, in reality, the higher PPEs for Secale are due to the fact that rye is the only wind-pollinated cereal while Hordeum and Triticum are autogamous (Vuorela 1973). Therefore, Secale releases much more pollen than the other cereals. The amount of pollen released from autogamous cereals may here be increased by the use of combine harvesters as opposed to traditional harvesting techniques (Vuorela 1973), which could be an explanation for the higher PPEs of southern Sweden compared to the Danish ones. It is noteworthy that the PPE of Secale estimated by Sugita et al. (1999) (3.0; recalculated relative to Poaceae instead of Juniperus) is very close to the south Swedish and Estonian PPEs. The REVEALS predicted regional abundance of cereals in southern Sweden using modern pollen assemblages from large lakes is closer to the actual abundance of cereals when the Danish PPE for cereals is used rather than the southern Swedish value (Hellman et al. 2008a, b). Therefore, it is suggested that the Danish PPE is a better value to 
use in areas where cereals are dominated by types other than Secale. An alternative explanation of the differences between PPEs of cereals may be overestimation of vegetation cover due to methodological differences in survey (see above; Soepboer et al. 2007a, b).

Several of the studies included were carried out in cultural landscapes maintained through different land use practices that may affect pollen productivity (for example Hjelle 1998; Broström et al. 2004; Mazier et al. 2008). Herb species in pastures are likely to have a lower-pollen productivity than in mown areas, especially if grazing pressure is high (Groenman-van Waateringe 1993). This is because grazing is performed continuously throughout the flowering season in a pasture, whereas mowing occurs only after the flowering season of most species in a meadow (Dahlström 2006). In southern Sweden, 40 moss polster samples were from grazed pastureland sites, and only two samples were from mown sites. In Norway, fourteen sites were grazed pastureland and seven sites were mown. In the Swiss Jura all study sites were grazed pastureland. The heathland areas of Sweden, Denmark and Norway have been burned and grazed, although grazing pressure in these sites is relatively low today. The three regions with lake data sets all comprise a mosaic of cultural landscape types as well as areas of natural vegetation. Because land use is similar across the majority of study areas, with moderate to high-grazing pressure except in heathland areas and mown meadows, the between-region differences in PPEs for the herb taxa are unlikely to be a result of variation in land management practices.

\section{Conclusions and recommendations}

1. PPEs are needed to apply the Landscape Reconstruction Algorithm of Sugita (2007a, b) for quantitative reconstruction of regional and local vegetation using the REVEALS and LOVE models, and for simulations and modelling of pollen dispersal and deposition (for example, Sugita et al. 1999; Bunting et al. 2004; Gaillard et al. 2008). PPEs are assumed to be constant through time and within the taxa for a given region.

2. PPEs for common tree and/or herb taxa are now available from nine study areas in Europe.

Some pollen types are recognised as consistently high pollen producers (Alnus, Betula, Quercus, Pinus, Calluna and Filipendula) or low pollen producers (Fraxinus, Salix, Tilia, Ulmus, Empetrum, Ericaceae other than Calluna, Vaccinium, Apiaceae, Compositae subfamily Cichorioideae and Leucanthemum, Anthemis type).

3. It is argued that much of the variation in PPEs between the study areas may be assigned to methodological differences for collection of vegetation data and choice of pollen samples (moss polsters or lake sediments). Environmental factors may cause variation in PPEs such as less flowering near species range limits, between-region differences in species and sub-species composition of individual taxonomic units, and differences in climatic characteristics or land-use practices.

4. Our recommendations for future pollen productivity estimate studies are:

a. Choice of taxa: The first step is to select the taxa for which PPEs are to be estimated. These taxa should be common in both the modern vegetation and the fossil pollen records of the study area.

b. Site number, site selection and type of pollen sample: The number of sites for collection of the pollen-vegetation data should be at least double the number of taxa included in the analysis. This is a mathematical constraint of the ERV models (Sugita, unpublished). Ideally, the sites should be randomly distributed in the study area (Broström et al. 2005; Mazier et al. 2008). If this is problematic, the sites should be selected so that the spread of values in vegetation cover is as large as possible for the taxa selected for the analysis.

c. Vegetation survey: the vegetation data should be obtained as absolute biomass if possible. Neither percentage cover nor frequency provides absolute biomass data. However, percentage cover is the best analogue to biomass and is the most timeefficient method of surveying vegetation at the various spatial scales required for generation of PPEs. The vegetation survey area should be large enough to include the relevant source area of pollen (RSAP) of the sites, sensu Sugita (1994). The RSAP of the study sites is generally not known and it is recommended that the RSAP is estimated by simulation analysis to assess the required spatial extent of the vegetation survey (Broström et al. 2004; Mazier et al. 2008). Such RSAP estimates can be obtained using hypothetical simple landscapes mimicking the modern landscape (Sugita et al. 1999; Mazier et al. 2008) or actual vegetation maps (Broström et al. 2005). In most of the studies performed so far, vegetation survey was performed within an area of 1,5002,000 $\mathrm{m}$ radius; however, well-dispersed taxa such as Pinus may require a larger survey area (Räsänen et al. 2007). The vegetation data should be collected in such a way that distance weighting is possible. Harmonization of the data collection in the field (vegetation survey and collection of pollen samples) would facilitate better comparison 
of PPEs between regions (see discussion above and Bunting and Hjelle 2008).

d. ERV analysis: The reference taxon used to calculate the relative PPEs should be characterised by a large spread of vegetation and pollen values. If PPEs are to be compared between several regions, the same reference taxon should be used. The PPEs should be estimated at or beyond the RSAP. It is useful to apply all ERV models and compare the results; this can provide a measure of quality of the PPEs. For a good understanding of the results, it is important to produce scatter plots of both the original and the ERV-adjusted pollen and vegetation data.

5. Our recommendations for the selection of PPEs for applications are as follows:

a. When studying the theoretical pollen-vegetation relationships in simulated landscapes, such as studies on pollen deposition in sites of various size and types, or studies on the RSAP, all alternative PPEs for the taxa involved should be used, and the results evaluated using the insights of the comparison presented in this paper. If the study relates to a particular geographical area and a particular vegetation type, one should select the most relevant PPEs at hand, that is, those existing for that area/ vegetation or those from the most comparable area/ vegetation (Hellman et al. 2008a, b).

b. For validation of the models included in the Landscape Reconstruction Algorithm (LRA), REVEALS and LOVE when using modern pollen and vegetation data, one should use the most relevant PPEs at hand, those existing for the geographical/vegetation area in which the validation is performed, or those from the most comparable area (Hellman et al. 2008a, b). In southern Sweden, it has been shown that the best fit between the REVEALS predicted vegetation and the actual surveyed vegetation was obtained with the PPEs from the same area (Broström et al. 2004), except for Cerealia, Plantago lanceolata, Rumex acetosa/acetosella and Calluna vulgaris, for which the PPEs from Denmark (Nielsen 2004) provided the best fit between model predictions and empirical data.

c. When applying REVEALS and LOVE to reconstruct past regional and local vegetation, consideration of past environmental variability within the region should be used to inform selection of PPEs; application of a range of possible PPEs will allow a better evaluation of the results bearing in mind that PPEs might have changed through time as a response to climatic change. The datasets reviewed here suggest that PPEs might differ between regions of different climate for taxa at their range limits when the mean January and July temperatures differ by $5-6^{\circ}$.

Acknowledgments This paper is a contribution to the POLLANDCAL (POLlen-LANDscape CALibration) network (http:// www.geog.ucl.ac.uk/ecrc/pollandcal/) sponsored by Nordforsk. We are very thankful to all POLLANDCAL members for useful and inspiring discussions during numerous network workshops (20012007). The manuscript was improved thanks to the helpful comments and suggestions from two anonymous referees. We also wish to thank Beate Helle for the layout of Fig. 2.

\section{References}

Andersen ST (1970) The relative pollen productivity and representation of north European trees, and correction factors for tree pollen spectra. Danmarks Geologiske Undersøgelse Række II 96:1-99

Anderson NJ, Bugmann H, Dearing JA, Gaillard MJ (2006) Linking palaeoenvironmental data and models to understand the past and to predict the future. Trends Ecol Evolut 21:696-704

Autio J, Hicks S (2004) Annual variations in pollen deposition and meteorological conditions on the fell Aakenustunturi in northern Finland: potential for using fossil pollen as a climate proxy. Grana 43:31-47

Bradshaw R (2007) Detecting human impact in the pollen record using data-model comparison. Veget Hist Archaeobot. doi: 10.1007/s00334-007-0116-8

Berglund BE, Gaillard MJ, Björkman L, Persson T (2007) Long-term changes in floristic diversity in southern Sweden-palynological richness, vegetation dynamics and land-use. Veget Hist Archaeobot. doi:10.1007/s00334-007-0094-x

Broström A (2002) Estimating source area of pollen and polen productivity in cultural landscapes of southern Sweden-developing a palynological tool for quantifying past plant cover. Doctoral thesis, Lund University, Lund

Broström A, Gaillard MJ, Ihse M, Odgaard B (1998) Pollenlandscape relationships in modern analogues of ancient cultural landscapes in southern Sweden-a first step towards quantification of vegetation openness in the past. Veget Hist Archaeobot 7:189-201

Broström A, Sugita S, Gaillard MJ (2004) Pollen productivity estimates for reconstruction of past vegetation cover in the cultural landscape of southern Sweden. Holocene 14:371-384

Broström A, Sugita S, Gaillard MJ, Pilesjö P (2005) Estimating spatial scale of pollen dispersal in the cultural landscape of southern Sweden. Holocene 15:252-262

Bunting MJ, Hjelle KL (2008) Effect of vegetation data collection strategies on estimates of relevant source area of pollen (RSAP) and relative pollen productivity (RPP) for non-arboreal taxa (submitted)

Bunting MJ, Gaillard MJ, Sugita S, Middleton R, Broström A (2004) Vegetation structure and pollen source area. Holocene 14:651660

Bunting MJ, Armitage R, Binney HA, Waller M (2005) Estimates of "relative pollen productivity" and "relevant source area of pollen" for major tree taxa in two Norfolk (UK) woodlands. Holocene 15:459-465

Calcote R (1995) Pollen source area and pollen productivity: evidence from forest hollows. J Ecol 83:591-602 
Caseldine C, Fyfe R (2006) A modelling approach to locating and characterising elm decline/landnam landscapes. Quat Sci Rev 25:632-644

Caseldine C, Fyfe R, Langdon C, Thompson G (2007a) Simulating the nature of vegetation communities at the opening of the Neolithic on Achill Island, Co. Mayo, Ireland-the potential role of models of pollen dispersal and deposition. Rev Palaeobot Palynol 144:135-144

Caseldine C, Fyfe R, Hjelle K (2007b) Pollen modelling, palaeoecology and archaeology-virtualisation and/or visualisation of the past? Veget Hist Archaeobot. doi:10.1007/s00334-007-0093-y

Dahlström A (2006) Grazing dynamics at different spatial and temporal scales: examples from the Swedish historical record A.D. 1620 1850. Veget Hist Archaeobot. doi:10.1007/s00334-006-0087-1

Davis MB (1963) On the theory of pollen analysis. Am J Sci 261:897-912

Duffin KI, Bunting MJ (2007) Relative pollen productivity and fall speed estimates for southern African savanna taxa. Veget Hist Archaeobot. doi:10.1007/s00334-007-0101-2

Eisenhut G (1961) Untersuchungen über die Morphologie und Ökologie der Pollenkörner heimischer und fremdländischer Waldbäume (English tr. by Jackson ST, Jaumann P 1989). Parey, Hamburg

Fyfe R (2006) GIS and the application of a model of pollen deposition and dispersal: a new approach to testing landscape hypotheses using the POLLANDCAL models. J Arch Sci 33:483-493

Gaillard MJ (2000) Development of the cultural landscape. In: Sandgren P (ed) Environmental changes in Fennoscandia during the Late Quaternary. LUNDQUA Report 37, Lund, pp 69-82

Gaillard MJ (2007) Pollen methods and studies-archaeological applications. In: Elias SA (ed) Encyclopedia of quaternary science, vol 3. Elsevier, Amsterdam, pp 2575-2595

Gaillard MJ, Birks HJB, Ihse M, Runborg S (1998) Pollen/landscape calibration based on modern pollen assemblages from surfacesediment samples and landscape mapping - a pilot study in south Sweden. In: Gaillard MJ, Berglund BE, Frenzel B, Huckriede U (eds) Quantification of land surface cleared of forest during the Holocene. (Paläoklimaforschung/Palaeoclimate Research 27) Fischer, Stuttgart, pp 31-52

Gaillard M-J, Sugita S, Bunting MJ, Middleton D, Hicks S, Broström A., Caseldine C, Giesecke T, Hjelle K, Langdon C, Nielsen A-B, Poska A, von Stedingk $\mathrm{H}$, Veski $\mathrm{S}$, and POLLANDCAL members* (2008) The use of simulation models in reconstructing past landscapes from fossil pollen data-research strategy and results from the POLLANDCAL network. Veget Hist Archaeobot

Gallandat JD, Gillet F, Havlicek E, Perrenoud A (1995) Typologie et systématique phyto-écologique des pâturages boisés du Jura suisse. Institut de botanique, Université de Neuchâtel

Gobat JM, Duckert O, Gallandat JD (1989) Quelques relations "microtopographie-sols-végétation" dans les pelouses pseudoalpines du Jura suisse: exemples d'un système naturel et d'un système anthropisé. Bull Soc Neuchâteloise Sci Nat 112:5-17

Grant MJ, Edwards ME (2007) Conserving idealized landscapes: past history, public perception and future management in the New Forest (UK). Veget Hist Archaeobot. doi:10.1007/ s00334-007-0100-3

Gregory PH (1973) The microbiology of the atmosphere. Leonard Hill, Aylesbury

Groenman-van Waateringe W (1993) The effects of grazing on the pollen production of grasses. Veget Hist Archaeobot 2:157-162

Hellman S, Gaillard MJ, Broström A, Sugita S (2008a) The REVEALS model, a new tool to estimate past regional plant abundance from data in large lakes: validation in southern Sweden. J Quat Sci 23:21-42
Hellman SEV, Gaillard M-J, Broström A, Sugita S (2008b) Effects of the sampling design and selection of parameter values on pollenbased quantitative reconstructions of regional vegetation: a case study in southern Sweden using the REVEALS model. Veget Hist Archaeobot. doi:10.1007/s00334-008-0149-7

Hicks S (1998) Fields, boreal forest and forest clearings as recorded by modern pollen deposition. In: Gaillard MJ, Berglund BE, Frenzel B, Huckriede U (eds) Quantification of land surface cleared forest during the Holocene (Paläoklimaforschung/Palaeoclimate Research 27) Fischer, Stuttgart, pp 53-66

Hicks S (2001) The use of annual arboreal pollen deposition values for delimiting tree-lines in the landscape and exploring models of pollen dispersal. Rev Palaeobot Palynol 117:1-29

Hjelle KL (1998) Herb pollen representation in surface moss samples from mown meadows and pastures in western Norway. Veget Hist Archaeobot 7:79-96

Mazier F, Brostöm A, Gaillard MJ, Sugita S, Vittoz P, Buttler A (2008) Pollen productivity estimates and Relevant Source Area for major taxa in a pasture woodland (Jura mountains, Switzerland). Veget Hist Archaeobot. doi:10.1007/s00334-008-0143-0

Moen A (1999) National atlas of Norway: vegetation. Norwegian Mapping Authority, Hønefoss

Moore PD, Webb JA, Collinson ME (1991) Pollen analysis. Blackwell, London

Nielsen AB (2003) Pollen-based quantitative estimation of land cover-relationships between pollen sedimentation in lakes and land cover as seen on historical maps in Denmark A.D. 1800. Doctoral thesis, University of Copenhagen

Nielsen AB (2004) Modelling pollen sedimentation in Danish lakes at c A.D. 1800: an attempt to validate the POLLSCAPE model. J Biogeogr 31:1693-1709

Nielsen AB, Odgaard BV (2004) The use of historical analogues for interpreting fossil pollen records. Veget Hist Archaeobot 13:3343

Olofsson J, Hickler T (2007) Effects of human land-use on the global carbon cycle during the last 6000 years. Veget Hist Archaeobot. doi:10.1007/s00334-007-0126-6

Parshall T, Calcote R (2001) Effect of pollen from regional vegetation on stand-scale forest reconstruction. Holocene 11:81-87

Parsons RW, Prentice IC (1981) Statistical approaches to $R$-values and pollen-vegetation relationship. Rev Palaeobot Palynol 32:127-152

Poska A, Sepp E, Veski S, Koppel K (2007) Using quantitative pollen-based land-cover estimations and a spatial CA_Markov model to reconstruct the development of cultural landscape at Rõuge, South Estonia. Veget Hist Archaeobot. doi:10.1007/ s00334-007-0124-8

Prentice IC (1985) Pollen representation, source area, and basin size: Toward a unified theory of pollen analysis. Quatern Res 23:76-86

Prentice IC, Parsons RW (1983) Maximum likelihood linear calibration of pollen spectra in terms of forest composition. Biometrics 39:1051-1057

Prentice IC, Webb T III (1986) Pollen percentages, tree abundances and the Fagerlind effect. J Quat Sci 1:35-43

Punt W, Blackmore S, Clarke GCS, Hoen PP (1976-1995) The Northwest European pollen flora. Elsevier, Amsterdam

Räsänen S, Hicks S, Odgaard BV (2004) Pollen deposition in mosses and a modified 'Tauber trap' from Hailuoto, Finland: what exactly does the moss record? Rev Palaeobot Palynol 129:103-116

Räsänen S, Suutari H, Nielsen AB (2007) A step further towards quantitative reconstruction of past vegetation in Fennoscandian boreal forests: Pollen productivity estimates for six dominant taxa. Rev Palaeobot Palynol 146:208-220

Soepboer W, Sugita S, Lotter A, Van Leuwen JFN, Van der Knaap WO (2007a) Pollen productivity estimates for quantitative 
reconstruction of vegetation cover on the Swiss Plateau. Holocene 17:1-13

Soepboer W, Vervoort JM, Sugita S, Lotter AF (2007b) Evaluating Swiss pollen productivity estimates using a simulation approach. Veget Hist Archaeobot. doi:10.1007/s00334-007-0128-4

Sugita S (1993) A model of pollen source area for an entire lake surface. Quat Res 39:239-244

Sugita S (1994) Pollen representation of vegetation in Quaternary sediments: theory and method in patchy vegetation. J Ecol $82: 881-897$

Sugita S (1998) Modelling pollen representation of vegetation. In: Gaillard MJ, Berglund BE, Frenzel B, Huckriede U (eds) Quantification of land surface cleared forest during the Holocene. (Paläoklimaforschung/ Palaeoclimate Research 27) Fischer, Stuttgart, pp 1-16

Sugita S (2007a) Theory of quantitative reconstruction of vegetation I: pollen from large sites REVEALS regional vegetation. Holocene 17:229-241

Sugita S (2007b) Theory of quantitative reconstruction of vegetation II: all you need is LOVE. Holocene 17:243-257

Sugita S, Andersen ST, Gaillard MJ, Mateus J, Odgaard B, Prentice IC, Vorren KD (1998) Modelling and data analysis for the quantification of forest clearence signals in pollen records. In: Gaillard MJ, Berglund BE, Frenzel B, Huckriede U (eds) Quantification of land surface cleared forest during the Holocene. (Paläoklimaforschung/Palaeoclimate Research 27) Fischer, Stuttgart, pp 125-131

Sugita S, Gaillard MJ, Broström A (1999) Landscape openness and pollen records: A simulation approach. Holocene 9:409-421

Sugita S, Gaillard MJ, Hellman S, Broström A (2008) Model-based reconstruction of vegetation and landscape using fossil pollen. In: Proceedings of 35th CAA (Computer Applications and Quantitative Methods in Archaeology) Conference, Berlin, April 2007

Sutton OG (1953) Micrometeorology. McGraw-Hill, New York

Wilmshurst J, McGlone M (2005) Origin of pollen and spores in surface lake sediments: comparison of modern palynomorph assemblages in moss cushions, surface soils and surface lake sediments. Rev Palaeobot Palynol 136:1-15

von Stedingk H, Fyfe R, Allard A (2008) Pollen productivity estimates for the reconstruction of past vegetation at the foresttundra ecotone. Holocene 18:323-332

Vuorela I (1973) Relative pollen rain around cultivated fields. Acta Bot Fennica 102:1-27 